\title{
Hydatid Disease in Childhood: A Single Center Experience
}

\section{Çocukluk Çă̆ında Kist Hidatik: Tek Merkez Deneyimi}

\author{
Deniz Aygün'(ID), Tarık Yıldırım²(iD ), Özlem Başoğlu Öner'(iD), Özgür Kuzdan(iD), Seyithan Özaydın(ID ), \\ Muhammet Erbaş̧(ID), Rengin Şiraneci' (ID) \\ ${ }^{1}$ Department of Pediatric Infectious Diseases, Istanbul Kanuni Sultan Suleyman Training and Research Hospital, Istanbul, Turkey \\ 2 Department of Pediatrics, Istanbul Kanuni Sultan Suleyman Training and Research Hospital, Istanbul, Turkey \\ ${ }^{3}$ Department of Pediatric Surgery, Istanbul Kanuni Sultan Suleyman Training and Research Hospital, Istanbul, Turkey \\ ${ }^{4}$ Department of Thoracic Surgery, Istanbul Kanuni Sultan Suleyman Training and Research Hospital, Istanbul, Turkey
}

\begin{abstract}
Cite this article as: Aygün D, Yıldıım T, Başoğlu Öner Ö, Kuzdan Ö, Özaydın S, Erbaş M, Şiraneci R. Hydatid disease in childhood: a single center experience. J Pediatr
\end{abstract} Inf 2020;14(2):e69-e75.

\begin{abstract}
Objective: Hydatid disease, caused by the Echinococcus species, is a zoonotic disease seen in the rural areas of the world. Although it is generally acquired in chilhood, pediatric reports are limited. Herein, we aimed to evaluate the demographic data and clinical process of children diagnosed with hydatid disease, which is still a widespread and important public health problem in our country.
\end{abstract}

Material and Methods: The medical records of patients hospitalized with the diagnosis of hydatid disease between June 2015 and August 2019 were evaluated retrospectively.

Results: There were a total of 56 patients, with 26 females and 30 males. Their median age was $10.25(2.75-17.5)$ years. Liver was the most frequently affected organ (55.4\%), followed by lungs (39.1\%), spleen (3.6\%), cardiac (1.8\%) and renal (1.8\%). The median size of the cysts in total was $6.0(1-12) \mathrm{cm}$. Seven patients had multicystic involvement. Twelve patients developed rupture of cysts. The patients who developed rupture had more symptoms of cough and fatigue and cysts larger than $5 \mathrm{~cm}$. Five patients had bronchial expansion, four patients developed secondary abscess formation, and three patients developed rupture of cyst to the bile duct.

Conclusion: Hydatid disease leads to a significant financial burden in developing countries. Prevention and control programs composed of health and personal habit education must be considered in endemic areas.

Keywords: Children, hydatid disease, clinical manifestations öz

Giriş: Echinococcus türlerinin neden olduğu kist hidatik dünyanın kırsal alanlarında görülen zoonotik bir hastalıktır. Hastalık genellikle çocukluk çağında kazanılmakla birlikte çocuklarda veriler sınırlıdır. Bu çalışmada ülkemiz için halen yaygın ve önemli bir halk sağlığı sorunu olan kist hidatik tanılı çocuk hastaların demografik ve klinik bulgularının değerlendirilmesi amaçlanmaktadır.

Gereç ve Yöntemler: Haziran 2015-Ağustos 2019 tarihleri arasında kist hidatik tanısıyla yatırılan hastaların tıbbi kayıtları incelendi.

Bulgular: Yirmi altı kız ve 30 erkek hastadan oluşan toplam 56 hasta vardı. Hastaların ortanca yaşları 10.3 (2.8-17.5) yıldı. Karaciğer en sık tutulan organdı (\%55.4), sırasıyla akciğer (\%39.1), dalak (\%3.6), kalp (\%1.8) ve böbrek (\%1.8) tutulumu vardı. Kistlerin ortanca boyutu $6.0(1-12) \mathrm{cm}$ idi. Yedi hastada multikistik tutulum vardı. On iki hastada kist perforasyonu gelişti, bu hastalarda öksürük ve yorgunluk şikayetleri daha fazlaydı ve kist boyutları 5 cm'den büyüktü. Beş hastada bronşiyal yayılım, dört hastada ikincil apse oluşumu ve üç hastada kistin safra yollarına yayılımı ile komplike oldu.

Sonuç: Kist hidatik gelişmekte olan ülkelerde ciddi bir ekonomik yüke neden olmaktadır. Hastalığın endemik olduğu bölgelerde kişisel alışkanlık ve sağlık eğitiminden oluşan önleme ve kontrol programları değerlendirilmelidir.

Anahtar Kelimeler: Çocuklar, kist hidatik, klinik bulgular

\author{
Correspondence Address/Yazışma Adresi \\ Deniz Aygün \\ Istanbul Kanuni Sultan Süleyman \\ Eğitim ve Araştırma Hastanesi, \\ Çocuk Enfeksiyon Hastalıkları Bölümü, \\ İstanbul-Türkiye \\ E-mail: fdenizaygun@gmail.com
}




\section{Introduction}

Hydatid disease (HD), first described by Hippocrates in ancient Greece, remains a common zoonotic disease (1-3). It is widespread in rural areas of the world such as Sub-Saharan Africa, South America, Asia, and Mediterranean countries, with an incidence rate reaching as high as 50 cases per 100000 people per year $(4,5)$. The incidence of HD is approximately 0.8 2.0/100000 people in Turkey (6). Besides being an important public health problem with a significant economic burden, an alarming number of deaths due to HD have been reported by the World Health Organization (WHO) (5). HD is caused by infections with the larval forms of Echinococcus species. Dogs are the definitive hosts for the disease while sheep and cows are intermediate hosts. Environmental and social factors of the area, such as poor sanitation and animal care, are important in the control and transmission of HD because humans are generally infected by ingesting the eggs of the parasites (6-8). Human infection leads to the development of one or more hydatid cysts in different organs in the body. Clinical manifestations of HD are not specific and can change according to the site of the cyst and the interaction between adjacent organs. The liver and lungs are the most commonly affected organs; however, the spleen, heart, kidney, and central nervous system can also be involved. $\mathrm{HD}$ is more commonly reported in childhood and adolescence, but pediatric reports and epidemiological data are limited.

We, therefore, aimed to evaluate the demographic, clinical, and laboratory data and treatment modalities of children hospitalized with the diagnosis of HD from a tertiary pediatric center located in a rural area of Istanbul, Turkey.

\section{Materials and Methods}

This retrospective single center study enrolled patients diagnosed with HD at Kanuni Sultan Suleyman Training and Research Hospital, Department of Pediatric Infectious Diseases, between June 2015 and August 2019. The medical records of patients were reviewed to obtain data regarding patient age, sex, animal contact history, symptoms, cyst location, cyst numbers and sizes, clinical findings. In laboratory, blood counts including neutrophil counts $\left(1500-7000 / \mathrm{mm}^{3}\right)$ and eosinophil $\left(350-500 / \mathrm{mm}^{3}\right)$, radiological imaging, treatment choices, and complications were recorded. Chest X-ray, abdominal or thorax ultrasonography, thorax, abdomen or cranial tomography, magnetic resonance imaging, and echocardiography were performed in all patients before treatment indication. Patients were evaluated serologically by an indirect hemagglutination test (IHA), and a readout of $\geq 1 / 320$ was considered positive for echinococcal infection. All patients received a medical treatment of albendazole (15 mg/kg/day), divided into two doses and controlled monthly for possible side effects after 15 days of treatment. In patients with a history of pre- and post-operative management, medical treatment was initiated
1-4 weeks prior to surgery as per WHO guidelines and continued for at least one month following surgery (9). Albendazole treatment was continued for at least six months in non-operated patients.

Surgical approach was considered for patients showing lung involvement. Either puncture-aspiration-injection-reaspiration (PAIR) or surgical treatment composed of cystotomy and capitonnage was performed for liver involvement.

At the end of the treatment period, patients were evaluated by clinical and radiological examination. Disappearance, collapse, or complete calcification of the cysts was accepted as cure while a decrease in size or change in the morphology of the cysts was considered partial improvement.

\section{Statistical Analysis}

Statistical analysis was performed using IBM SPSS Statistics (Windows Version 21.0. Armonk, NY: IBM Corp.). Continuous variables were presented as median (with range) and categorical variables as frequencies (with percentages). Normal distribution of continuous data was tested by Kolmogorov Smirnov test. Significance value was $<0.05$ for most of the demographic and prognostic factors in this test. Therefore, we compared continuous variables using chi-square and Mann-Whitney U-test for non-parametric data. For all tests, $\mathrm{p}<0.05$ was considered to be statistically significant. Approval from the local ethics committee of Kanuni Sultan Suleyman Training and Research Hospital was received for the study (2019.05.132). A signed informed consent form was obtained from all parents of the patients in this study.

\section{Results}

A total of 56 patients hospitalized with the diagnosis of HD at the Department of Pediatric Infectious Diseases were enrolled in the present study. Of our sample, 26 (46.4\%) patients were females and $30(53.6 \%)$ were males. Their median age was 10.3 (2.8-17.5) years. Twenty-five (44.6\%) patients had a history of contact with canines. All patients lived in rural areas of Istanbul and had low socioeconomic status. Low socioeconomic status was determined as families who work with minimum wage. Nineteen (33.9\%) patients had the history of visiting their hometown where they performed husbandry.

Abdominal pain was the most common symptom in the HD sample $(n=31,55.4 \%)$, followed by cough $(n=28,50 \%)$, fever $(n=24,42.9 \%)$, chest pain $(n=16,28.6 \%)$, fatigue $(n=10$, $17.9 \%)$, hemoptysis $(n=4,7.1 \%)$, jaundice $(n=3,5.3 \%)$, skin rash and pruritus $(n=2,3.6 \%)$, and expectoration of salty fluid $(n=2,3.6 \%)$. Two (3.6\%) patients were asymptomatic and diagnosed incidentally. Seven (12.5\%) patients had a history of trauma. The most common physical finding among patients was decreased breath sounds $(n=21,37.5 \%)$. Pulmonary crackle ( $n=10,17.9 \%)$, hepatomegaly $(n=5,8.9 \%)$, hepato- 
Table 1. Demographic, clinical, laboratory and radiologic findings of patients

\begin{tabular}{|l|l|}
\hline Patient number & $\mathbf{n}=\mathbf{5 6}(\%)$, or median (min-max) \\
\hline $\begin{array}{l}\text { Sex } \\
\text { Male }\end{array}$ & $30(53.6 \%)$ \\
\hline Age & $26(46.4 \%)$ \\
\hline Symptoms of Patients & 10.25 years (2.75-17.5) \\
Abdominal pain & \\
Cough & $31(55.4 \%)$ \\
Fever & $28(50 \%)$ \\
Chest pain & $24(42.9 \%)$ \\
Fatigue & $16(28.6 \%)$ \\
Hemoptysis & $10(17.9 \%)$ \\
Jaundice & $4(7.1 \%)$ \\
Skin rash & $3(5.3 \%)$ \\
Expectoration of bitter fluid & $2(3.6 \%)$ \\
Asymptomatic & $2(3.6 \%)$ \\
\hline Physical Findings & $2(3.6 \%)$ \\
\hline Normal & \\
Decreased breath sounds & $26(46.4 \%)$ \\
Pulmonary crackle & $10(17.9 \%)$ \\
Hepatomegaly & $5(8.9 \%)$ \\
Hepatosplenomegaly & $2(3.6 \%)$ \\
Urticaria & $2(3.6 \%)$ \\
\hline Rupture of cysts & $12(21.4 \%)$ \\
\hline Eosinophilia & $17(30.4 \%)$ \\
\hline Leukocytosis & $21(37.5 \%)$ \\
\hline Echinococcal IHA positivity & $37(69.1 \%)$ \\
\hline Median size of the cysts & $6.0 \mathrm{~cm} \mathrm{(1-12)}$ \\
\hline Cysts > 5 cm & $38(67.3 \%)$ \\
\hline Multiple cysts & $7(12.5 \%)$ \\
\hline Giant cyst ( $\geq 10$ cm) & $8(14.3 \%)$ \\
\hline & \\
\hline
\end{tabular}

splenomegaly $(n=2,3.6 \%)$, and urticaria $(n=2,3.6 \%)$ were other physical findings. Physical examination was normal in 26 (46.4\%) patients. Demographic findings, clinical symptoms and physical findings of the patients are shown in Table 1.

With regard to the localization of the cysts, 24 (42.9\%) patients had only liver involvement, 14 (25\%) patients had both liver and lung involvement, 13 (23.2\%) patients had only lung involvement, 2 (3.6\%) patients had both liver and spleen involvement, 1 (1.8\%) patient had lung and spleen involvement, $1(1.8 \%)$ patient had only cardiac involvement, and $1(1.8 \%)$ patient had liver, spleen, lung and renal involvement. Radiographic imaging of the patients with hydatid cysts is presented in Figures 1-3.

HD was detected in the right lobe of the liver in $51.8 \%$ of the patients ( $n=29)$, and in the left lobe in $26.8 \%$ of patients $(n=15)$. With regard to lung involvement, $15(26.8 \%)$ patients had cysts in the right lobe, $14(25 \%)$ patients had cysts in the left lobe, 20 (35.7\%) patients had cysts in the lower lobe, and

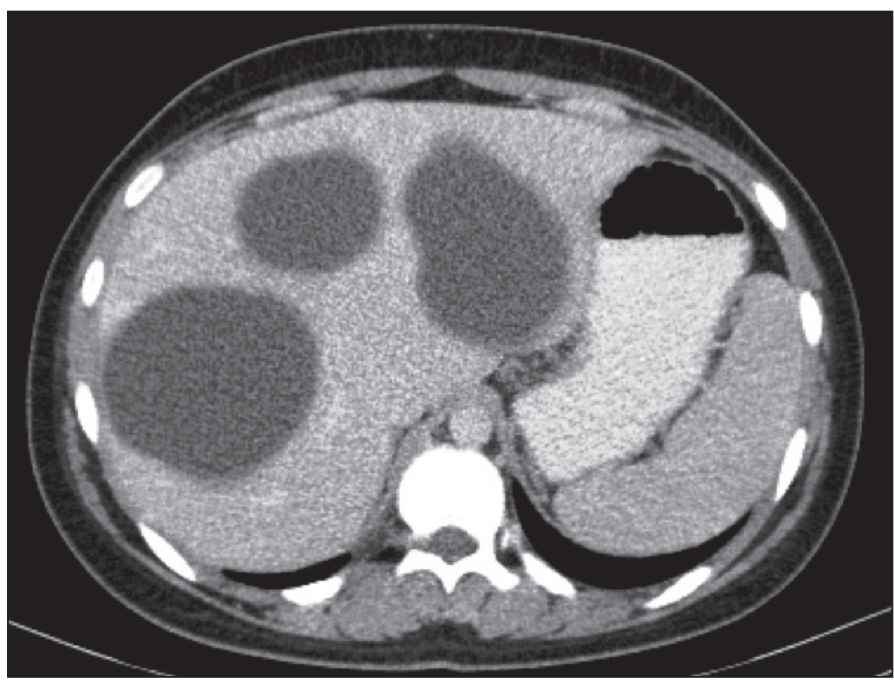

Figure 1. Abdomen tomography showing hydatid cysts in liver.

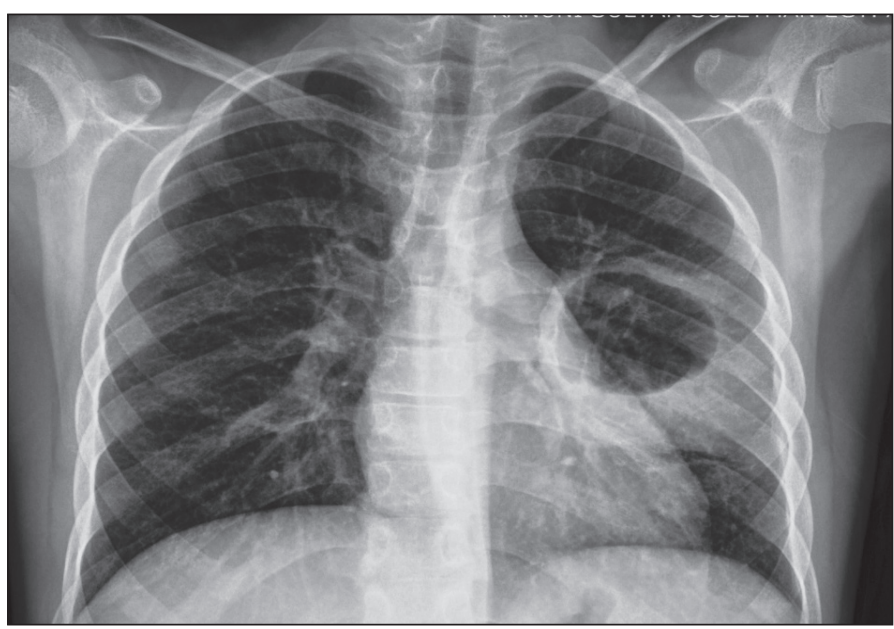

Figure 2. Chest X-ray of lung cyst in the left lobe.

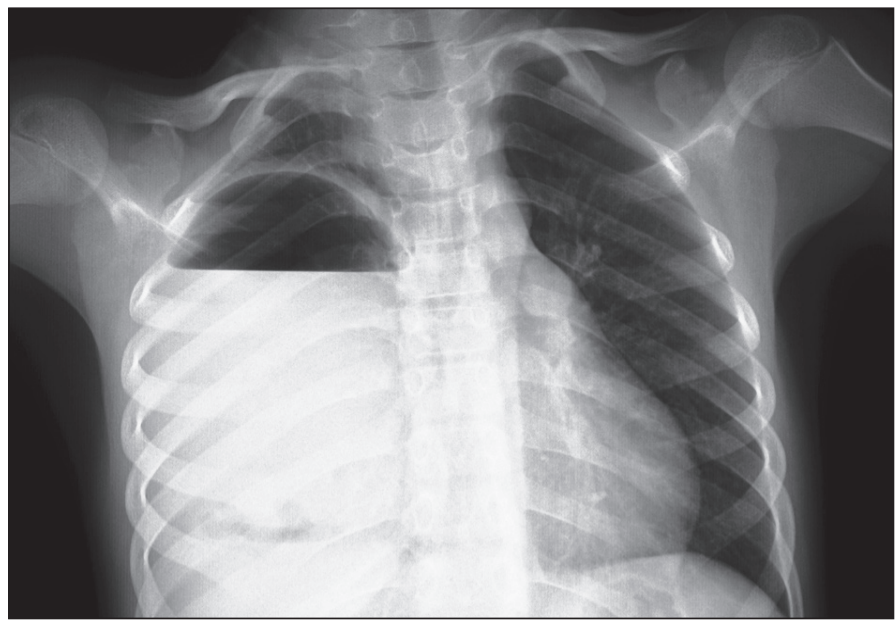

Figure 3. Chest X-ray of lung cyst in the right lobe.

$10(17.9 \%)$ patients had upper lobe involvement. Localization of the cysts is shown in Table 2. 
Table 2. Localization of the cysts

\begin{tabular}{|l|l|}
\hline Localization & Patient number $(\mathbf{n = 5 6 , \% )}$ \\
\hline Liver & $24(42.9)$ \\
Liver and lung & $14(25)$ \\
Lung & $13(23.2)$ \\
Liver and spleen & $2(3.6)$ \\
Lung and spleen & $1(1.8)$ \\
Cardiac & $1(1.8)$ \\
Liver, spleen, lung and renal & $1(1.8)$ \\
\hline Right lobe of liver & $29(51.8)$ \\
Left lobe of liver & $15(26.8)$ \\
Right lobe of lung & $15(26.8)$ \\
Left lobe of lung & $14(25)$ \\
Lower lobe of lung & $20(35.7)$ \\
Upper lobe of lung & $10(17.9)$ \\
\hline \multicolumn{2}{|l}{} \\
\hline
\end{tabular}

The median size of the cysts in total was $6.0(1-12) \mathrm{cm}$. Eighteen (32.1\%) patients had small cysts $(\leq 5 \mathrm{~cm})$, and 38 (67.3\%) patients had cysts $>5 \mathrm{~cm}$. Eight (14.3\%) patients had cysts $\geq 10 \mathrm{~cm}$. Seven (12.5\%) patients showed multicystic involvement.

Thirty-seven (66.1\%) patients had echinococcal IHA positivity. As patients were classified according to IHA results,
27 (71.9\%) patients had readout values of 1/2560, 2 (5.4\%) patients had readout values of 1/1280, 2 (5.4\%) patients had readout values of $1 / 640$, and $6(16.1 \%)$ patients had readout values of $1 / 320$. At the end of the treatment period, $51.8 \%$ of the patients showed decreased echinococcal IHA levels. In diagnosis, median eosinophil count was $314(0-3400) / \mathrm{mm}^{3}$ and median percentage was $3.9 \%(0-39)$. Eosinophilia was present in $30.4 \%$ of patients $(n=17)$. Median leukocyte count amongst patients was $11895(3510-22220) / \mathrm{mm}^{3}$. Leukocytosis was present in $37.5 \%$ of patients $(n=21)$. Median neutrophil count 6955 (2100-17210)/mm ${ }^{3}$, median lymphocyte count $2550(600-8600) / \mathrm{mm}^{3}$.

As patients were monitored for complications of HD, 12 (21.4\%) patients developed ruptured cysts. Five patients with lung involvement had bronchial expansion and four patients developed secondary abscess formation. Three patients with liver involvement developed ruptured cysts in the bile duct and had clinical findings of cholecystitis. No difference was found between patients who showed cyst rupture in terms of age at the time of diagnosis, sex, trauma history, complaints of fever, chest pain, hemoptysis, multicystic involvement, IHA positivity, leukocytosis and eosinophilia, but rupture was more common in the case of cysts $>5 \mathrm{~cm}(p=0.044)$ and correlated

Table 3. The comparison of characters of patients

\begin{tabular}{|c|c|c|c|}
\hline & $\begin{array}{l}\text { Rupture } \mathrm{n}=12(\%) \text {, or } \\
\text { median (min-max) }\end{array}$ & $\begin{array}{l}\text { No rupture } n=44(\%) \text {, or median } \\
\text { (min-max) }\end{array}$ & $p$ \\
\hline Sex (female) & $4(33.3 \%)$ & $22(50 \%)$ & 0.244 \\
\hline Age (year, median) & $11.8(6.2-16.3)$ & $10(2.8-17.5)$ & 0.903 \\
\hline Cyst size $>5 \mathrm{~cm}$ & $11(91.6 \%)$ & $27(61.4 \%)$ & 0.044 \\
\hline Multicytic involvement & $2(16.7 \%)$ & $5(11.4 \%)$ & 0.470 \\
\hline History of trauma & $1(8.3 \%)$ & $6(13.6) \%$ & 0.530 \\
\hline Cough & $12(100 \%)$ & $16(36.4 \%)$ & $<0.001$ \\
\hline Fatigue & $6(50 \%)$ & $4(9 \%)$ & 0.004 \\
\hline Fever & $8(66.6 \%)$ & $16(36.4 \%)$ & 0.061 \\
\hline Chest pain & $5(41.7 \%)$ & $11(25 \%)$ & 0.217 \\
\hline Hemoptysis & $2(16.7 \%)$ & $2(4.5 \%)$ & 0.198 \\
\hline IHA positivity & $7(58.3 \%)$ & $30(68.2 \%)$ & 0.377 \\
\hline Leucocytosis & $7(58.3 \%)$ & $14(31.8 \%)$ & 0.091 \\
\hline Eosinophilia & $6(50 \%)$ & $18(41 \%)$ & 0.404 \\
\hline Median size of the cysts (cm) & $7.7(5-12)$ & $5.9(1-11)$ & 0.004 \\
\hline Leucocyte count $\left(10^{3} / \mu \mathrm{L}\right)$ & $14360(6560-20930)$ & $11480(3510-22220)$ & 0.192 \\
\hline Neutrophil count $\left(10^{3} / \mu \mathrm{L}\right)$ & 10500 (3500-14500) & 6385(2100-17210) & 0.131 \\
\hline Lymphocyte count $\left(10^{3} / \mu \mathrm{L}\right)$ & $2100(1000-4000)$ & $3000(600-8600)$ & 0.124 \\
\hline Eosinophil count $\left(10^{3} / \mu \mathrm{L}\right)$ & $385(0-2000)$ & $300(0-3400)$ & 0.839 \\
\hline Alanine aminotransferase (IU/L) & $11(2-140)$ & $14(4-242)$ & 0.465 \\
\hline Aspartate aminotransferase (IU/L) & $20(10-50)$ & $22(9-349)$ & 0.458 \\
\hline
\end{tabular}


Table 4. Treatment modalities of the patients

\begin{tabular}{|l|l|}
\hline & $\mathbf{n}(\%)$ \\
\hline Lung & \\
Surgery and medical & $28(96.5)$ \\
Only medical & $1(3.5)$ \\
\hline Liver & \\
Surgery and medical & $21(37.5)$ \\
Only medical & $15(26.8)$ \\
PAlR and medical & $5(8.9)$ \\
\hline $\begin{array}{l}\text { Spleen } \\
\text { Surgery and medical }\end{array}$ & $2(50)$ \\
Only medical & $2(50)$ \\
\hline $\begin{array}{l}\text { Cardiac } \\
\text { Surgery and medical }\end{array}$ & $1(100)$ \\
\hline Renal & \\
Surgery and medical & $1(100)$ \\
\hline
\end{tabular}

with increased frequency of cough and fatigue ( $p<0.001, p=$ $0.04)$. The comparison of the characteristics of patients is presented in Table 3.

When patients were considered for treatment, 17 (30.4\%) patients received only medical treatment, $34(60.7 \%)$ patients received both surgical and medical treatment, and 5 (8.9\%) patients received PAIR and medical treatment. As treatment modalities were considered according to organ involvement, only 1 (3.4\%) patient with pulmonary HD received only medical treatment, whereas $96.5 \%$ of patients with pulmonary HD opted for surgical treatment. Surgical and medical treatment was performed in $37.5 \%$ of the patients, medical treatment only was performed in $26.8 \%$, whereas PAIR and medical treatment was performed in $8.9 \%$ of the patients with liver HD. Treatment modalities of the patients are listed in Table 4. An increase in liver enzymes was observed in one patient during albendazole treatment, though we did not experience any other adverse effects with medical treatment. At the end of the treatment period, patients were evaluated by clinical and radiological examination. We did not experience any mortality or recurrence of cysts, and all patients showed clinical and radiological improvement.

\section{Discussion}

Our study focused on the demographic and clinical findings and treatment of choices of HD in the pediatric age group. HD is a serious public health concern in the central and eastern regions of Turkey, where farming is a prominent source of livelihood $(6,10,11)$. Possible routes of infection include ingestion of eggs contaminated by water and poorly washed vegetables and fruits (12-15). Further, we experience a significant number of HD cases in suburban and underdeveloped locations of Istanbul with low socioeconomic status.
$\mathrm{HD}$ is more commonly reported in males in the international literature, and the percentage of male patients in the current report was also higher than females (53.6\%). It is assumed that a higher history of animal contact and some behavioral habits in males could explain this sex-related difference $(16,17)$.

HD can affect almost any site of the body, and single organ involvement is reported in $85-90 \%$ of cases $(4,18,19)$. In the current study, $67.8 \%$ of patients had single organ involvement, whereas $32.2 \%$ of the patients had multi-organ involvement. The liver is affected in approximately two-thirds of the adult patients, whereas pulmonary involvement is reported to be higher in children $(8,19-21)$. The vascularization, compressible nature, and negative pressure of the lungs in children are assumed to be the reason for this $(22,23)$. In a large pediatric report from Greece, $51.3 \%$ of the pediatric patients had lung involvement (1). Çakır et al. have also reported higher lung involvement in children with HD from Turkey (24). In our study, $55.4 \%$ of the patients had liver involvement and $39.1 \%$ of patients had lung involvement. These results are consistent with reports from both Turkey and other countries. In a pediatric report from Bulgaria with an 18-year study period, HD cysts have been detected with the highest frequency in the liver (13). Kara et al. have also reported high liver involvement (11). The spleen, heart and kidney were the other less frequently affected organs in our study. Cardiac involvement is reported in $0.2-3 \%$ of all HD patients; only $1(1.8 \%)$ of our patients had cardiac HD. Consistent with the literature, right lobe of the liver was affected in the majority of patients (1). In children, right lower lung lobes are the most affected parts of the lungs, as observed in the current study (25).

Children generally have single cysts, whereas multiple cysts are reported in up to $34.2 \%-45.5 \%$ of the patients $(26,27)$. Only $12.5 \%$ of our patients had multicystic involvement. The growth of cysts occurs slowly, and many of the patients can remain asymptomatic for years, while some cysts can even spontaneously regress. Cysts $<5 \mathrm{~cm}$ are termed as small cysts; herein, $32.1 \%$ of the patients had small cysts, while $67.3 \%$ of patients had cysts $>5 \mathrm{~cm}$. Cysts $>10 \mathrm{~cm}$ are termed "giant cysts' and were present in $14.3 \%$ of our patients.

Clinical spectrum of HD depends on the site and size of the cysts and the interaction between adjacent organs. Patients with liver HD usually have complaints of abdominal discomfort, pain, fever, and jaundice. Chest pain, cough, and hemoptysis are common symptoms of patients with lung HD. Children with lung HD can be asymptomatic due to the high elasticity of the lung parenchyma and a weakened immune response (28). Most of the symptoms of our patients were consistent with those observed in previous reports. 
Cyst rupture is a principal complication of $\mathrm{HD}$, and was present in $21.4 \%$ of our patients. The patients who developed ruptured cysts had a higher frequency of cough and fatigue, as well as large cysts $(>5 \mathrm{~cm})$ in the present study. Cysts in the liver can rupture into the biliary tree with an incidence of 3-17\% and can lead to obstructive jaundice, cholangitis, cholecystitis, liver abscess, pancreatitis, and even septicemia (29-31). Three patients developed cholecystitis due to cyst rupture and bile duct leakage, which was treated with cholangiography and cholecystectomy.

Cysts in the lung may rupture into the pleural cavity, leading to pneumothorax, pleural effusion, or empyema $(23,32)$. Cysts can also rupture into the bronchial tree, and we observed this in four of our patients. The cyst was located in the right lower lobe in two of these patients, in the right upper lobe in one of these patients, and in the left upper lobe in one of these patients. A salty taste in the mouth and hemoptysis can be signs of ruptured pulmonary cysts, both of which were present in $10.7 \%$ of our patients. Hemoptysis is a relatively rare sign of HD in children compared to adults (32). Hemoptysis can be due to cyst rupture into the bronchus, pressure erosion, or obstruction of bronchus with a secondary bacterial infection. Four of our patients experienced hemoptysis: two of them had bronchial expansion and two of them developed a secondary bacterial abscess. Another important complication is the infection of the cyst, manifesting as a pulmonary abscess, which was present in four of our patients.

Eosinophilia accompanies $20-34 \%$ of HD cases (1). Eosinophilia was present in $30.4 \%$ of our patients. Leukocytosis was present in $37.5 \%$ of the patients. Leukocytosis and eosinophilia are more commonly reported in cases of ruptured cysts (32); however, we did not experience any statistical significance in leukocytosis and eosinophilia in patients with ruptured or non-ruptured cysts $(p=0.091, p=0.404)$.

Serologic tests such as Echinococcus-specific IHA, specific ELISA immunoglobulin (lg) G, specific lgE, latex agglutination or immunoelectrophoresis, are used for the diagnosis of HD due to their low cost and easy applicability. The diagnostic utility of these tests has frequently been compared. Although there is not yet a consensus about the ideal test, specific ELISA IgG is reported to be the most sensitive diagnostic method used $(8,33)$. We were able to perform only echinococcal IHA, which showed a positive result in $66.1 \%$ of the patients. The reliability of IHA is limited due to cross reactions with other cestode infections. Further, as a negative serology does not rule out HD, IHA positivity does not make a definitive diagnosis, but rather supports it. It is necessary to note that IHA positivity can last for years even after treatment.

There is no standard therapeutic option for HD. The management of HD depends on patient's age, location, number and structure of cysts and presence of complications. Surgery is the main treatment for lung HD. Generally, parenchyma protective surgery composed of cystotomy and capitonnage is the preferred method of treatment for children. Lobectomy and pneumonectomy, which causes loss of parenchyma, are not recommended, especially in endemic areas due to the risk of recurrence $(32,34)$. Treatment approaches are controversial for giant cysts. Some authors prefer lobectomy, whereas others perform cystotomy and the capitonnage technique (34). We had four patients with giant cysts, but lobectomy was performed only in one patient. Cystotomy and capitonnage was performed in $93.1 \%$ of the patients with lung involvement. The role of medical treatment, specifically benzimidazoles, in lung HD is contentious. It is reported to be effective in approximately $70 \%$ of lung HD by softening the cysts, reducing intracystic pressure, and enabling cyst removal (32). Benzimidazoles are not recommended in case of larger cysts because they increase the risk of cyst rupture due to their effect on weakening the cyst wall (30). We stopped albendazole treatment in one patient with a $13-\mathrm{cm}$ cyst in the lung prior to surgery.

There is no single effective treatment option for liver HD. PAIR can be considered in case of simple and accessible cysts by USG or CT-guided administration of $20 \%$ hypertonic saline. PAIR is contraindicated for superficial and calcified cysts or cysts with bile duct communication $(8,35)$. We were able to perform PAIR in only five patients due to technical limitations. Surgery, which is the definitive cure for large and infected cysts, was performed in 21 patients. Medical treatment was considered in 15 patients with uncomplicated and small cysts.

Prognosis of HD is generally good in children. Recurrence rates vary between $2-25 \%$ depending on the location of the cyst and the choice of treatment (24). All patients in our study recovered completely and no recurrence was detected during the course of our study.

Our study has some limitations. First, it was a single-center, retrospective study; thus, the results cannot be extrapolated. Second, we did not have the WHO-Informal Working Group on Echinococcosis (WHO-IWGE) ultrasound classification for all patients; therefore, we could not evaluate their treatment plans. Finally, we could not compare the efficacies of treatment procedures. Multicenter studies with larger sample sizes are necessary to verify the choice of treatment and provide information on long term follow-up results of patient outcomes.

\section{Conclusion}

HD should be tested in children admitted to hospital with different complaints and signs, especially in endemic and rural areas. The treatment should be regulated by considering clinical, radiological, and serologic test results. Further, the prevention and control programs composed of health and personal habit education are important in lowering the incidence of HD. 
Ethics Committe Approval: Approval from the local ethics committee of Kanuni Sultan Suleyman Training and Research Hospital (2019.05.132) was received for the study.

Informed Consent: Consent from all parents of our patients was received for the study.

Peer-review: Externally peer-reviewed.

Author Contributions: Concept - DA, RŞ; Design - DA, RŞ; Supervision - ÖK, SÖ, ME, ÖBÖ, TY; Data Collection and/or Processing - DA, ÖBÖ, TY, SÖ, ÖK, ME; Analysis and/or Interpretation - DA,RŞ; Literature Review - DA, TY; Writing - DA; Critical Review - RŞ.

Conflict of Interest: No conflict of interest was declared by the authors.

Financial Disclosure: The authors declared that this study has received no financial support.

\section{References}

1. Petropoulos AS, Chatzoulis GA. Echinococcus granulosus in childhood: a retrospective study of 187 cases and newer data. Clin Pediatr (Phila) 2019;58:864-88. [CrossRef]

2. Craig PS, McManus DP, Lightowlers MW, Chabalgoity JA, Garcia HH, Gavidia CM, et al. Prevention and control of cystic echinococcosis. Lancet Infect Dis 2007;7:385-394. [CrossRef]

3. Mandal S, Mandal MD. Human cystic echinococcosis:epidemiologic, zoonotic, clinical, diagnostic and therapeutic aspects. Asian Pac J Trop Med 2012;5:253-60. [CrossRef]

4. Bhutani N, Kajal P. Hepatic echinococcosis: a review. Ann Med Surg (Lond) 2018;36:99-105. [CrossRef]

5. World Health Organization. Echinococcosis. http://www.who.int/echinococcosis/en/. Accessed April 18, 2019. [CrossRef]

6. Uysal A, Gürüz Y, Köktürk O. Türk Toraks Derneği Paraziter Akciğer Hastalıkları Tanıve Tedavi Uzlaşı Raporu. Turkish Thoracic Journal 2009;10(Suppl B). [CrossRef]

7. Yang YR, Sun T, Li Z, Zhang J, Teng J, Liu X. Community surveys and risk factor analysis of human alveolar and cystic echinococcosis in Ningxia Hui Autonomous Region, China. Bull World Health Organ 2006;84:71421. [CrossRef]

8. Ammann RW, Eckert J. Cestodes. Echinococcus. Gastroenterol Clin North Am 1996;25:655-89. [CrossRef]

9. Brunetti E, Kern P, Vuitton DA. Writing panel for the WHO-IWGE. Expert consensus for the diagnosis and treatment of cystic and alveolar echinococcosis in humans. Acta Trop 2010;114:1-16. [CrossRef]

10. Anadol D, Özçelik U, Kiper N, Göçmen A. Treatment of hydatid disease. Paediatr Drugs 2001;3:123-5. [CrossRef]

11. Tural-Kara T, Özdemir H, Karbuz A, Kocabaş BA, Yahsi A, et al. Clinical characteristics of childhood hydatid disease: a single tertiary centre experience from Turkey. HK J Paediatr (new series) 2018;23:162-8. [CrossRef]

12. Amahmid O, El Guamri Y, Zenjari K, Bouhout S, Ait Moh M, Boraam F, et al. The pattern of cystic echinococcosis in children in an endemic area in Morocco. J Parasit Dis 2019:43:209-14. [CrossRef]

13. Jordanova DP, Harizanov RN, Kaftandjiev IT, Rainova IG, Kantardjiev TV. Cystic echinococcosis in Bulgaria 1996-2013, with emphasis on childhood infections. Eur J Clin Microbiol Infect Dis 2015;34:1423-8. [CrossRef]

14. Craig PS, McManus DP, Lightowlers MW, Chabalgoity JA, Garcia HH, Gavidia CM, et al. Prevention and control of cystic echinococcosis. Lancet Infect Dis 2007;7:385-94. [CrossRef]
15. The European Union summary report on trends and sources of zoonoses, zoonotic agents and food-borne outbreaks in 2010. Euro Surveill. 2012;17(10). pii: 20113. [CrossRef]

16. Tantawy MI. Hydatid cysts in children. Ann Pediatr Surg 2010;6:98-104. [CrossRef]

17. Aslanabadi S, Zarrintan S, Abdoli-Oskouei S, Salehpour F, Zarrintan $A$, Beheshtirouy $S_{\text {, }}$ et al.Hydatid cyst in children: a 10-year experience from Iran. Afr J Paediatr Surg 2013;10:140-4. [CrossRef]

18. Escola-Verge L, Salvador F, Sanchez-Montalva A, Escudero-Fernandez $J M$, Sulleiro $E$, Rando A, et al. Retrospective study of cystic echinococcosis in a recent cohort of a referral center for liver surgery. $J$ Gastrointest Surg 2019;23:1148-56. [CrossRef]

19. McManus DP, Zhang W, Li J, Bartley PB. Echinococcosis. Lancet 2003;362:1295-304. [CrossRef]

20. Arminanzas C, Gutierrez-Cuadra M, Farinas MC. Hidatidosis: aspectos epidemiologicos, clinicos, diagnosticos y terapeuticos. Rev Esp Quimioter 2015;28:116-24. [CrossRef]

21. Siracusano A, Teggi A, Ortona E. Human cystic echinococcosis: old problems and new perspectives. Interdiscip Perspect Infect Dis 2009;2009:474368. [CrossRef]

22. Arroud M, Afifi MA, El Ghazi K, Nejjari C, Bouabdallah Y. Lung hydatic cysts in children: comparison study between giant and non-giant cysts. Pediatr Surg Int 2009; 25:37-40. [CrossRef]

23. Santivanez S, Garcia HH. Pulmonary cystic echinococcosis. Curr Opin Pulm Med 2010;16:257-61. [CrossRef]

24. Çakır D, Çelebi S, Gürpınar A, Agın M, Bozdemir E. Evaluation of cases with hydatid diseases. J Pediatr Inf 2009;3:104-8. [CrossRef]

25. Morar R, Feldman C. Pulmonary echinococcosis. Eur Respir J 2003;21:1069-77. [CrossRef]

26. Djuricic SM, Grebeldinger S, Kafka DI, Djan I, Vukadin M, Vasiljevic $Z V$. Cystic echinococcosis in children -the seventeen-year experience of two large medical centers in Serbia. Parasitol Int 2010;59:257-61. [CrossRef]

27. Dopchiz MC, Elissondo MC, Andresiuk MV, Maiorini E, Gutierrez AM, Muzulin PM, et al. Pediatric hydatidosis in the south-east of the Buenos Aires province, Argentina. Rev Argent Microbiol 2009;41:105-1. [CrossRef]

28. Kocer B, Gulbahar G, Han S, Durukan E, Dural K, Sakinci U. An analysis of clinical features of pulmonary giant hydatid cyst in adult population. Am J Surg 2009;197:177-81. [CrossRef]

29. Eckert J, Deplazes P. Biological, epidemiological, and clinical aspects of echinococcosis, a zoonosis of increasing concern. Clin Microbiol Rev 2004;17:107-35. [CrossRef]

30. Paksoy M, Karahasanoglu T, Carkman S, Giray S, Senturk H, Ozcelik F, et al. Rupture of the hydatid disease of the liver into the biliary tracts. Dig Surg 1998;15:25-9. [CrossRef]

31. Zaouche A, Haouet K, Jouini M, El Hachaichi A, Dziri C. Management of liver hydatid cysts with a large biliocystic fistula: multicenter retrospective study. World J Surg 2001;25:28-39. [CrossRef]

32. Sarkar M, Pathania R, Jhobda A, Thakur B, Chopra R. Cytic pulmonary hydatidosis. Lung India 2016;33:179-91. [CrossRef]

33. Zarzosa MP, Orduna Domingo A, Gutierrez $P$, et al. Evaluation of six serological tests in diagnosis and postoperative control of pulmonary hydatid disease patients. Diagn Microbiol Infect Dis 1999;35:255-2. [CrossRef]

34. Onal O, Demir OF. Is anatomic lung resection necessary in surgical treatment of giant lung hydatid cysts in childhood? Ann Thorac Cardiovasc Surg 2017;23:286-90. [CrossRef]

35. Brunetti E, Junghanss T. Update on cystic hydatid disease. Curr Opin Infect Dis 2009;22:497-502. [CrossRef] 